\title{
PATTERN FORMATION OF BUSINESS CONDITIONS IN DOMESTIC MARKET OF CROP PRODUCTION
}

\author{
Svitlana STRAPCHUK ${ }^{1}$ \\ Semen Kuznets Kharkiv National Economic University, Ukraine
}

\begin{abstract}
The purpose of the article is to detect crop production on agricultural enterprises clusters at a price by defining their amplitude of price fluctuations. Methodology. The study is based on grouping of statistical data from agricultural enterprises using cluster analysis, followed by reliability evaluation of pre-selected clusters by t-test and charting the scope by the selected index. Cluster analysis of agricultural enterprises in Ukraine has been conducted using "STATISTICA" program. Distance between clusters was calculated as the Euclidean distance. The object of the study was data on the prices for agricultural enterprises by regions of Ukraine in 2013. As a result, an appropriate number of groups according to the produce types in the regions of Ukraine, plane in market prices, have been determined. The process of consistent combination of objects in clusters is shown in the graphs as agglomerative clustering dendrogram of the regions of Ukraine for such products as wheat, grain corn and sunflower seeds. In general, there have been examined: 7311 businesses growing wheat, 5034 - growing corn and 6124 companies growing sunflower. Results. During a year-long study of price fluctuations in agricultural enterprises within regions of Ukraine similarities in nature of absolute and relative changes in the formed clusters were established. Four clusters on wheat, five clusters on corn, three clusters on sunflower seeds have been allocated during the study. The study of the selected groups confirms significant differences between them and allows the sectors and enterprises of the cluster with high variability of prices to build their own marketing strategy based on the position of expectations and search for sale options according to the most favorable price. Practical value. The established differences on the selected clusters make it possible to forecast the price situation in various regions of Ukraine in terms of its differences from average by clusters for each product. Accordingly, it will enable specific producers to define the marketing strategy for pricing in the region for each product. Value/originality. The data on groups of growing crops permit to select forecast marketing strategies or rapid sale according to the prevailing prices.
\end{abstract}

Key words: cluster analysis, agricultural enterprises, crop products, price, the price of clusters, $t$-criterion, magnitude chart, standard errors, significance level.

JEL Classification: L10, M31, Q13

\section{Introduction}

The problem of choice of the most typical objects for study with the purpose of a detailed analysis, which is always urgent, requires the use of modern methods and techniques. One of the most effective and quite popular methods today to search for patterns of market conditions formation is the method of cluster analysis that allows classifying mixed statistical sets. Its main advantage is the ability to unite disparate objects on one or more indicators into groups (clusters). Cluster analysis is an inductive method of research used to classify objects. As the objects are difficult to distribute into groups, it is appropriate to make calculations by an agglomerative hierarchical clustering method that is a consistent association of closest objects in one cluster.

The use of cluster analysis in economics is widely discussed in the works of such scholars as P.L. Gordienko
(2008), I.M. Pistunov (2008), O.M. Tyshchenko (2010), and others.

Based on the above, we can formulate a research problem which is to identify clusters on the crop production market at a price that will allow selecting marketing strategies of expectations or rapid sale at prevailing prices for the period.

\section{Clustering of agricultural enterprises according to wheat price}

In 2013, 7311 agricultural enterprises in Ukraine received revenue from the sale of wheat; they were divided into 4 clusters by the selling price (Figure 1). The selected groups have no territorial binding, and are formed based on the characteristics of the market. It has been found out that despite similar average values

\footnotetext{
Corresponding author:

${ }^{1}$ Department of Business Economics and Management, Semen Kuznets Kharkiv National Economic University.

E-mail: baysvetlana@yandex.ru
} 
within the clusters themselves, they have different levels of variability and standard deviations from the average value (Figure 2). The first of these clusters that includes 3842 economic entities of the corporate sector (52\% of the total) from 10 regions -AR Crimea, Donetsk, Luhansk, Chernihiv, Kharkiv, Mykolaiv, Dnipropetrovsk, Odesa, Kherson, Kyiv, has average price of $1406.2 \mathrm{UAH}$., and intra group variation was $226.8 \mathrm{UAH}$.

In the second of the selected clusters which includes 1,489 enterprises in Zhytomyr, Zaporizhzhia, Kirovohrad and Cherkasy regions, the average price is the highest- $1440.8 \mathrm{UAH}$. / $\mathrm{t}$ with significant standard deviation at $284.5 \mathrm{UAH}$, that is $20.3 \%$ of the average price.

On the diagram cluster 1 differs by the hight of the rectangle and the length of straight lines - standard errors. In establishing the difference between the average values of the first and second clusters by t-test we have obtained a significance level less than 0.05. Similar low value levels were obtained by comparing the second and third clusters, the second and the fourth one. Consequently, the values within the clusters are rather different, that is, the null hypothesis of the average equality and dispersions uniformity is rejected, which means that cluster 2 is substantially different from the selected clusters 1, 3 and 4 . The difference between the selected groups is also confirmed by the correlation coefficients and standard deviations. The third cluster of wheat on the market was formed by the fewest number of agricultural enterprises - 560 units from 4 regions of Ukraine - Ivano-Frankivsk, Chernivtsi, Vinnytsia and Transcarpathia.

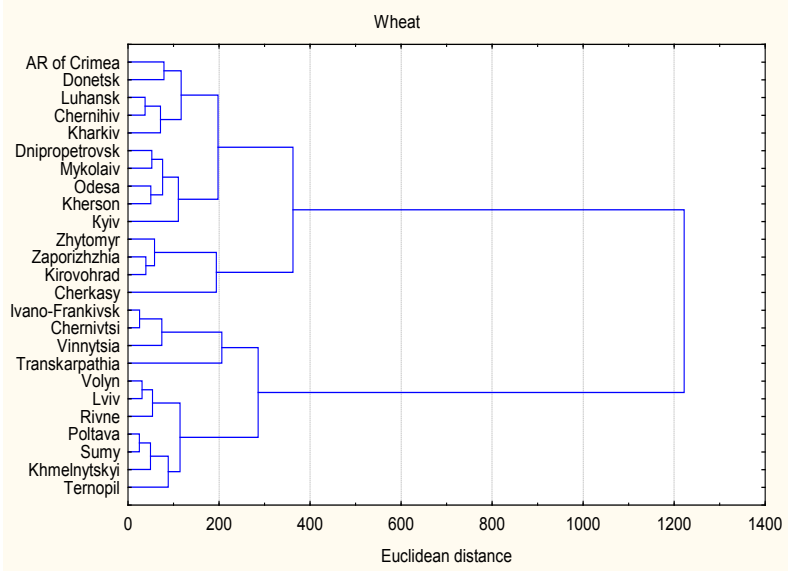

Fig. 1. Dendrogram of agglomerative hierarchical clustering for the price of 1 ton of wheat as per agricultural enterprises of Ukraine in 2013

Source: State Statistics Committee of Ukraine and the author's calculations (by form № 50 agr )

It should be noted that the average price is 1402.9 UAH. / $t$, while the smallest difference in prices is 145.9 USD. (10.4\% of average).

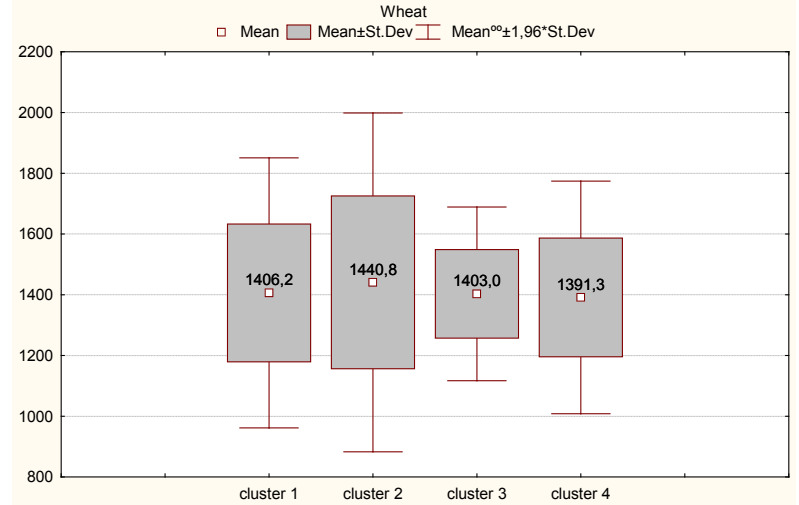

Fig. 2. Diagram of prices per 1 ton of wheat

Source: the author's calculations (as to form № 50-agr)

After the comparison of the third cluster average with other existing ones using t-test, a high level of significance $(p<0,02)$ of cluster 2 and 3 has been found out, which shows heterogeneity of wheat market in the selected groups and high values of $p$ - index in comparison with clusters 1 and 3, 3 and 4, that proves the similarities between them.

The last, the fourth cluster includes 1,420 agricultural enterprises of Volyn, Lviv, Rivne, Poltava, Sumy, Khmelnytsky and Ternopil regions, the average price there was $1391.3 \mathrm{UAH}$. /t. The observed difference between the average of the fourth and the second clusters by $\mathrm{t}$-criterion has a significance level $p=0,005$, confirming the differences in market conditions formation according to the price in these groups.

Close connection between the selected groups has been established by calculating the correlation coefficients for the average values of prices (Table. 1).

Table 1

Correlation matrix of interdependencies of average values of wheat prices between different clusters as per agricultural enterprises of Ukraine in 2013

\begin{tabular}{|l|c|c|c|c|}
\hline & Cluster 1 & Cluster 2 & Cluster 3 & Cluster 4 \\
\hline Cluster 1 & 1,000 & & & \\
\hline Cluster 2 & 0,953 & 1,000 & & \\
\hline Cluster 3 & 0,813 & 0,779 & 1,000 & \\
\hline Cluster 4 & 0,861 & 0,825 & 0,785 & 1,000 \\
\hline
\end{tabular}

Source : the author's calculations (as to form № 50-agr)

The data given in the table indicate a close relationship between the selected clusters, as the lowest value of the correlation coefficient is 0.779 for cluster 3 and cluster 4 , while the highest value 0.953 has been received between the first and the second group. This gives grounds to assert the existence of the wheat market with a highly competitive price, the closer the relationship, the higher the competition and the slightest signs of price regulation. 


\section{Clustering of agricultural enterprises according to the price of corn.}

5034 enterprises received the revenue from the sales of corn in 2012 in Ukraine. Based on the market price of corn we have allocated five clusters presented in the dendrogram (fig. 3).

Thus, the cluster includes 1690 companies in four regions - AR Crimea, Transcarpathian, Vinnytsia and Cherkasy with average price of $1350.7 \mathrm{UAH} . / \mathrm{t}$. Difference in prices within the selected group is about $15.2 \%$ of the level, i.e. 206.1 UAH. In pair comparison of the first cluster with the second by t-test a value of significance level has been determined which indicates the similarity of the two selected groups. Subsequent comparison of the first cluster with the third, fourth and fifth, on the contrary, confirmed the differences between them, as the level of significance of $p<0.05$.

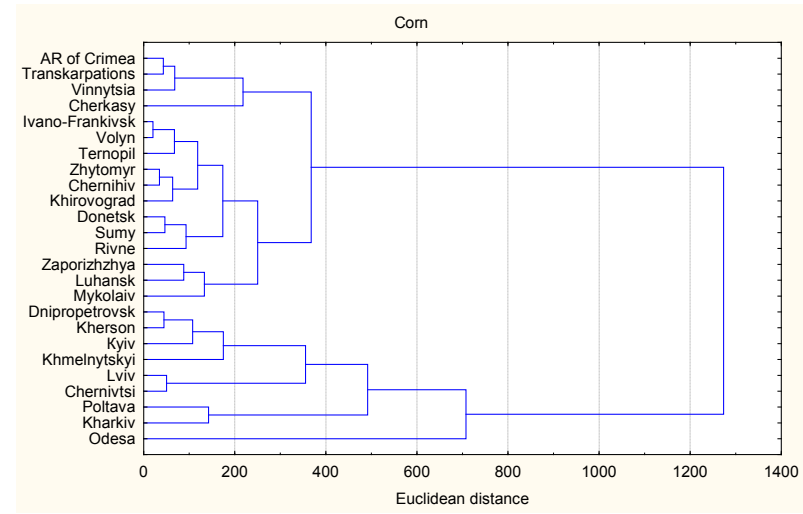

Fig. 3. Dendrogram of hierarchical agglomerative clustering for the price of 1 ton of corn as per agricultural enterprises in Ukraine in 2013

Source: State Statistics Committee of Ukraine and the author's calculations (as to form № 50-agr)

In the second cluster of enterprises of IvanoFrankivsk, Volyn, Ternopil, Zhytomyr, Chernihiv, Kirovograd, Donetsk, Sumy, Rivne, Zaporizhzhia, Luhansk and Mykolaiv regions formed at the price of $2069 \mathrm{UAH}$ (41\% of total) difference in prices is within $189 \mathrm{UAH}$., which is $14 \%$ of the average price level equal to $1339.8 \mathrm{UAH}$. (figure 3 ).

Checkup by the t-test to identify differences between the average value of two clusters indicates differences in groups 2 and 3, 2 and 4 , and 2 and 5, i.e. the significance level is less 0.05 .

The third cluster is characterized by the lowest height of the rectangle, which is the smallest divergence in prices. This indicates that the corn market in agricultural enterprises of Dnipropetrovsk, Kherson, Kyiv, Khmelnytsky, Lviv and Chernivtsi regions is more developed with a high level of competition among buyers. It consists of 1,087 agricultural enterprises, i.e. $22 \%$ of the total number. Therefore, differences in the prices which they offer to producers are minimal. The average level of prices in the cluster is 1399.2 UAH and the scale of standard error is average of 155.6 UAH (11\% of the price).

The fourth cluster includes 820 enterprises in Poltava and Kharkiv regions that sold corn at an average price of $1424.6 \mathrm{UAH} / \mathrm{t}$ at a standard deviation of 261.3 $\mathrm{UAH}$, i.e. $18 \%$ of the price level. Conducted $\mathrm{t}$-analysis has confirmed the high level of significance, except for links between the third and fourth clusters, where $\mathrm{p}=$ 0.09 . This is evidence of differences between the groups and it confirms possible overregulation of the market and the state intervention in market mechanisms in the formation of prices on the market of corn grain prices. Odessa region was allocated into a separate fifth cluster, which has record highest sale price for sunflower seeds with their average of $1558.1 \mathrm{UAH}$. / t. In this case difference in prices is significant, $27 \%$ of the average prices, in absolute terms it is $418.9 \mathrm{UAH}$.

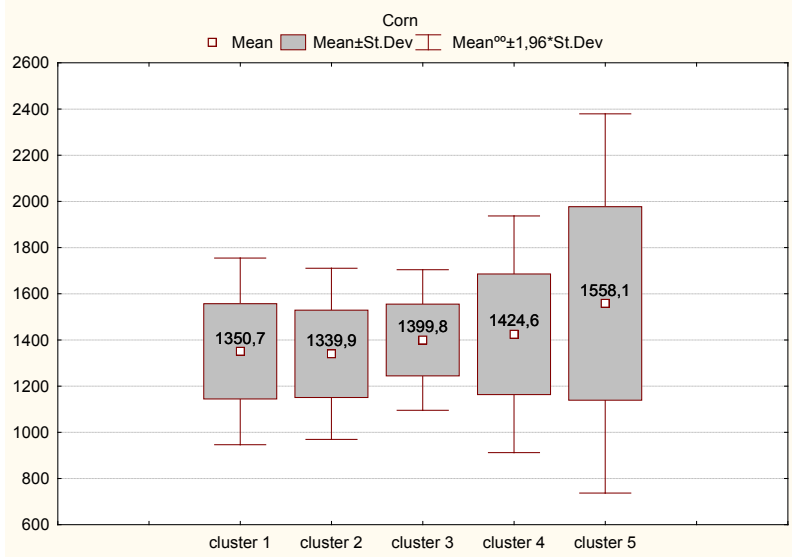

Fig. 4. Diagram of prices per 1 ton of corn

Source: the author's calculations (as to form № 50-agr)

To establish a connection between the selected clusters we have calculated the correlation between their average values (table 2).

High values of correlation coefficients ranging from 0.7 to 1.0 , observed between clusters 1 and 3, 4 and 3, 3 and 5 and 4 and 5 is evidence of the close relationship between the groups, moreover, a strong link exists between 4 and 3-0.911 and 1 and 3 clusters -0.822 , while groups 1 and 4 are less associated.

Table 2

Correlation matrix of interdependencies of average price values of corn between different clusters as per agricultural enterprises of Ukraine in $\mathbf{2 0 1 3}$

\begin{tabular}{|l|c|c|c|c|c|}
\hline & Cluster 1 & Cluster 2 & Cluster 3 & Cluster 4 & Cluster 5 \\
\hline Cluster 1 & 1,000 & & & & \\
\hline Cluster 2 & 0,202 & 1,000 & & & \\
\hline Cluster 3 & 0,822 & 0,634 & 1,000 & & \\
\hline Cluster 4 & 0,662 & 0,564 & 0,911 & 1,000 & \\
\hline Cluster 5 & 0,609 & 0,465 & 0,776 & 0,752 & 1,000 \\
\hline
\end{tabular}

Source: the author's calculations (as to form № 50-agr) 
A weak link has been established between cluster 1 and 2, where the correlation coefficient is 0.202 . A moderate link can be seen between 1 and 5, 3 and 2, 4 and 2, 5 and 2, indicating the differences in the formation of these groups.

\section{Clustering of agricultural enterprises according to the price of sunflower seeds}

Similar dendrograms have been constructed for other types of products. Let us consider the grouping scheme according to the price of sunflower seeds in detail (figure 5).

Analyzing the price situation in the market of sunflower seeds in Ukraine, 3 clusters have been allocated among 6124 agricultural enterprises that received income from their sale; the first cluster is the largest, comprising 2,446 enterprises from 14 regions of Ukraine, while the second includes 3364 enterprises from 10 regions, the third - 314 enterprises of Kyiv region only. Diagram 6 shows identical in size rectangles of first and second clusters.

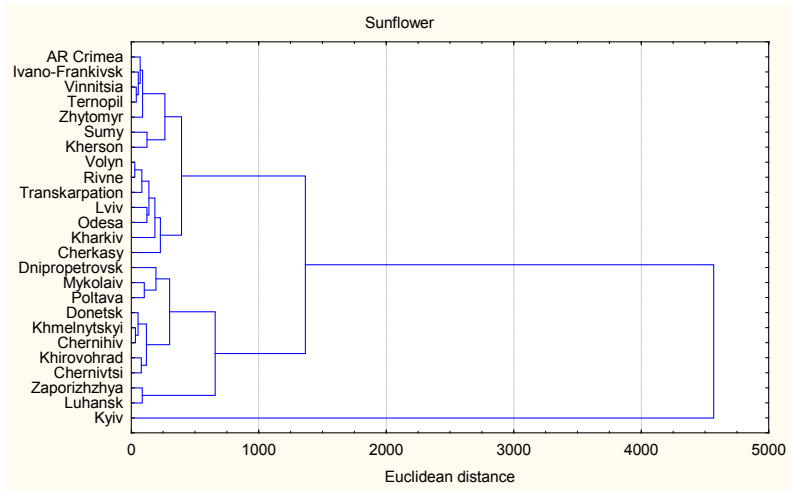

Fig. 5. Dendrogram of agglomerative hierarchical clustering according to the price of 1 t of sunflower seeds in Ukraine agricultural enterprises of Ukraine in 2013

Source: State Statistics Committee of Ukraine and the author's calculations (as to form № 50-agr)

According to the calculations, the difference in the standard deviation is insignificant - in absolute values standard deviation of 1 cluster is $318.8 \mathrm{UAH}$, the second - $323.7 \mathrm{UAH}$, whereas in \% ratio both calculations show $9.5 \%$ of the average price .

Apart from minor differences in the prices, the first cluster has the lowest average price of $3360.6 \mathrm{UAH}$. / $\mathrm{t}$, which is $2 \%$ lower than in the second cluster and $18 \%$ lower than in the third. It includes enterprises in Crimea, Ivano-Frankivsk, Vinnytsia, Ternopil, Zhytomyr, Sumy, Kherson, Volyn, Rivne, Transcarpathian, Lviv, Odesa, Kharkiv and Cherkasy regions. In this case the $\mathrm{t}$-criterion in pair comparison reveals a low level of significance between the first and the second, the first and the third clusters, which is evidence of nonuniform price situation in these groups, confirming the validity of this distribution.

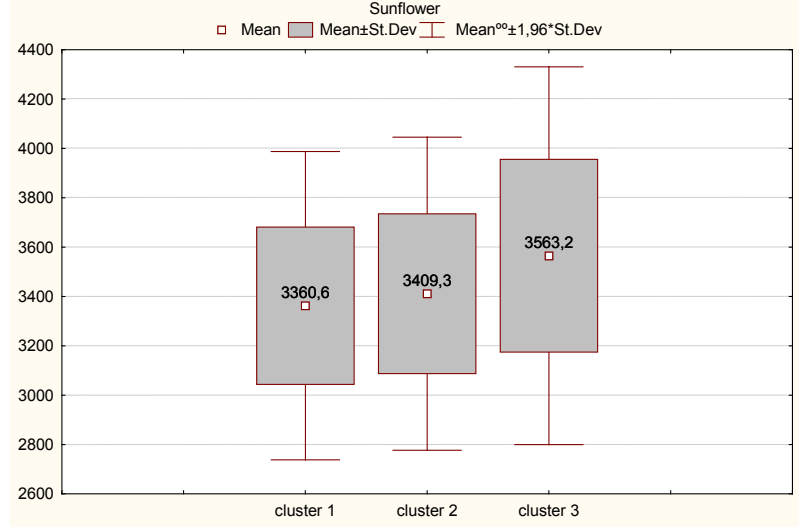

Fig. 6. The scope of prices of 1 ton of sunflower seed

Source: the author's calculations (as to form № 50-agr)

The average price of the second cluster is $3409.2 \mathrm{UAH} / \mathrm{t}$, standard deviation is $9.5 \%$ of the average price. According to t-test low significant level between clusters 2 and 3 have been revealed, which also confirms the validity payments in the allocated groups.

The third cluster includes only Kyiv region, due to the higher limit of the standard error of $11 \%$ of the average price value compared with the previous two groups. Data verification for the distress correlation between the selected clusters (Table. 3 ) has confirmed the strong link between the second and the third clusters.

Table 3

Correlation matrix of interdependencies of average price values of sunflower seeds between different clusters as per agricultural enterprises of Ukraine in 2013

\begin{tabular}{|c|c|c|c|}
\hline & Cluster 1 & Cluster 2 & Cluster 3 \\
\hline Cluster & 1,000 & & \\
\hline Cluster 2 & 0,744 & 1,000 & \\
\hline Cluster 3 & 0,750 & 0,871 & 1,000 \\
\hline
\end{tabular}

Source: the author's calculations (as to form № 50-agr)

The correlation coefficient between them is 0.871 , while between the first and the second clusters it is slightly weaker, correlation coefficient is 0.744 , and there is a connection between the first and the third cluster 0.750 . Thus, the difference between the selected clusters has been confirmed.

\section{Conclusions}

While studying the price fluctuations in agricultural enterprises of the regions of Ukraine during 2013, similar character of absolute and relative changes in the formed clusters is established. Research of these clusters in terms of substantial differences between them using a T-test comparing averages in the two groups has shown that the most significant differences in wheat were noted between clusters 2 (Zhytomyr, 
Zaporizhzhia, Kirovohrad, Cherkasy region) and cluster 3 (Ivano-Frankivsk, Chernivtsi, Vinnytsia, Transcarpathian), on grain corn - between cluster 3 (Dnipropetrovsk, Kherson, Kyiv, Khmelnytsky, Lviv and Chernivtsi regions) and cluster 5 (Odessa region). The established differences on the selected clusters enable us to forecast a price situation in various regions of Ukraine in terms of its differences from the average values in clusters for each product. Accordingly, it will enable specific producers to determine a pricing marketing strategy in the region for each type of the product.

\section{References}

Gordiyenko, P.L. (2008). Strategic analysis, K.: Alerta, 404 p.

Pistunov, I.M. (2008). Cluster analysis in economics. Dnipropetrovsk: National Mining University, 84 p.

Tyshchenko, O.M. (2010). Clusters as a vector in economic development: organization, essence and concepts. Theoretical and applied issues of economics, 21: 74-80.

\section{Светлана СТРАПЧУК}

\section{ВЫЯВЛЕНИЕ ЗАКОНОМЕРНОСТЕЙ ФОРМИРОВАНИЯ КОНЪЮНКТУРЫ ВНУТРЕННЕГО} РЫНКА ПРОДУКЦИИ РАСТЕНИЕВОДСТВА

Аннотация. Целью статьи является выявление на рынке продукции растениеводства сельскохозяйственных предприятий кластеров по цене с определением в них амплитуды ценовых колебаний. Методика. Исследование основано на группировке статистических данных сельскохозяйственных предприятий с использованием кластерного анализа с последующим оцениванием достоверности значений выделенных кластеров по t-критерию и построением диаграмм размаха по выделенным кластерам. Кластерный анализ сельскохозяйственных предприятий Украины по цене было осуществлено помощью программы "STATISTICA". Величину расстояния между кластерами рассчитывали как эвклидова расстояние. Объектом исследования стали данные по ценам на сельскохозяйственных предприятиях по областям Украины за 2013 г. В результате было получено соответствующее количество групп по видам продукции по областям Украины в плоскости рыночных цен. Процесс последовательного объединения объектов в кластеры показаны на графиках в виде дендрограммы агломеративной кластеризации регионов Украины для таких видов продукции как пшеница, кукуруза на зерно и подсолнечник. В целом обследовано по выращиванию пшеницы - 7311 предприятий, по выращиванию кукурузы 5034 предприятий и по выращиванию подсолнечника - 6124 предприятия. Результаты. Во время исследования ценовых колебаний по сельскохозяйственных предприятиях областей Украины в течение года было установлено сходство характера абсолютных и относительных изменений по сформированным кластерам. Было выделено по пшенице четыре кластера, по кукурузе - пять, по подсолнечнику - три кластера. Исследование выделенных групп подтверждает наличие существенных различий между ними и позволяет предприятиям кластера, где высокая вариативность цены, строить собственную маркетинговую стратегию на основе позиции ожидания и поиска вариантов реализации по наиболее благоприятной цене. Практическое значение. Различия по выделенным кластерам дают возможность спрогнозировать ценовую ситуацию в различных регионах Украины с точки зрения ее отличий от средних по кластерам по каждому виду продукции. Соответственно это даст возможность конкретным производителям определять маркетинговую стратегию относительно формирования цены в данном регионе по каждому виду продукции. Значение/оригинальность. Полученные данные по группам выращивания культур позволяют выбрать маркетинговые стратегии ожидания или быстрой реализации по сложившимся ценам. 